\title{
Implications of Musical Education in Creativity Develop
}

\author{
Óscar Costa Román1, Vicenta Gisbert Caudeli² \\ ${ }^{1}$ Universidad Autónoma de Madrid, Madrid, Spain \\ ${ }^{2}$ Universidad de la Laguna, San Cristóbal de La Laguna, Spain \\ Email: ocostar@gmail.com, vicenta.gisbert@gmail.com
}

How to cite this paper: Román, Ó. C., \& Caudeli, V. G. (2019). Implications of Musical Education in Creativity Develop. Creative Education, 10, 200-207.

https://doi.org/10.4236/ce.2019.101016

Received: December 5, 2018

Accepted: January 22, 2019

Published: January 25, 2019

Copyright $\odot 2019$ by author(s) and Scientific Research Publishing Inc. This work is licensed under the Creative Commons Attribution International License (CC BY 4.0).

http://creativecommons.org/licenses/by/4.0/

\begin{abstract}
Nowadays society requires people to be capable of resolving the existing problems and creating new ones. But also it is necessary to develop people available to understand and love arts and also to prepare able people practice it like expression forms. In contrast, in the Spanish education politicization, there are important differences between regions about the study loads of arts and creativity. In these lines it is presented the next paper where the authors make a review about creativity, the situation of musical education and the connection between musical education and creativity in the Spanish's primary school with the target of increasing the students' cognitive development.
\end{abstract}

\section{Keywords}

Creativity, Musical Education, Cognitive Develop, Primary School

\section{Introduction}

Music is one of the most important artistic, cultural and folk representations, in every social group. This idea was supported by Iniesta Masmano's (2014) who said that music is always present in our society, operating such as a meeting point between human diversity and the things that other cultures have in common: the emotions, from their intrinsic proprieties (organization of the composition) to extrinsic, of their social nature is extremely important.

As explains Griffiths (2009)

"Children need listening adults who will take turns to create shared meanings in playful contexts. Practitioner guidance is strongly needed at this time on creative ways to implement the themes of the new Foundation Stage Framework, i.e. listening together, playing and learning outdoors, music and dance, number, shapes and problem solving, being me, and mark making and representation." 
By contrast, over the last years, the Spanish educational system has reduced the hours at school in subjects, such as Physical Education, Arts and Crafts, and also in Musical Education. Moreover, it is essential to check how at the Kindergarten degree that must prepare professionally to the students who will work as teachers from zero to six years old, only has a maximum of eight ECTS credits; however, future teachers will spend lots of hours in this area.

This issue is repeated throughout all the compulsory educational stages (Primary School and Secondary School), where music is an optional subject and, in many cases, schools have freedom to put this subject in their studies. In this form it is required to say that musical education has been extinct from the classrooms.

From another point of view, authors like Herrera, Hernández-Candelas, Lorenzo and Ropp (2014), connected to the teacher's instruction in the musical area with the amount of time aimed to the educational and cognitive development of the students, explaining that how bigger is the preparation of the teachers, and more hours devote to the musical education, bigger is the cognitive development of the students.

Finally, and following to Díaz (2009), it is necessary to say that in the last decades, creativity has been, and it remains the same, one of the more refuses concepts and maybe understood in the educative environment. For this reason, before continuing with this topic, it should be important to clarify the concept of creativity.

\section{Definition of Creativity}

What is creativity? This question has been presented for many authors. At the beginning, it was attributed to God or the musses. Nowadays, it is shown like a "muscle" that can be exercised. Following to Chyle (1999), it is important to mention:

"Obviously, inquire regarding creativity is a difficult task. Next to the problem of defining what exactly one investigates, researchers also need to define the orientation of one's investigation. Historically, there are 3 main orientations in which creativity has been conceptualized. Naturalism (all events occur in an entirely lawful empirical scientifically knowable universe) rationalism (a less empirical view explaining phenomena in terms of a set of principles that specify a structure of relationships necessary for this phenomena) and supernaturalism (explanations are not based on the natural processes, but on supernatural such as god or the muse). Investigators have espoused at least one of three broad orientations, orientations based upon fundamental assumptions about the admissible content of explanations as well as appropriate methods for obtaining information. I believe that these three orientations are important to have in mind when reading or thinking about creativity. Since a lot of unconscious idea forming is in the baggage of the word creativity, and these three broad orientations may underlie misconceptions about-or favouritism for a certain perspec- 
tive on creativity. Research on creativity becomes even more problematic, since these phenomena cannot be studied or explained in a traditional model of cause and predictions. The essence of creativity is to defy predictions because it affirms the presence of discontinuity and spontaneity (Rothenberg \& Hausman, 1976). "There is an unavoidable paradox. creations ... are in some way recognizable and familiar to us ... However, creations in the most complete sense, are also radically new and therefore, in some respect, unfamiliar. Therefore creativity is both determined and undetermined at the same time (Rothenberg \& Hausman, 1976, p. 23)." (pp. 18-19)

To put it in another way, we should make a reference to Corbalan Berná (2008) who says that creativity is the capacity to create new questions and problems and resolve the existing ones with different forms.

One of the most contemporary references about creativity is by Costa (2017), who explains:

It is possible to define the creativity as the inherent human capacity whereby are activated the cognitive process in that, thanks to external incentives, a person gives a new utility to a resource pre-existing or create a new tool in order to give a solution to a problem or the capacity to draw up a problem in the correct way, which can be resolved by others.

\section{Creativity in Childhood}

Following Krumm, Vargas, Lemos and Oros (2015), it is necessary to say that as Huidobro-Salas (2002) mentions, the surrounding atmosphere of every person is essential to develop creativity, being the absence of obstacles, availability of resources, exposure to a variety of models at the childhood age, the recognition of creative behaviours and a family and social environment that encourages individualism, different aspects that improve creativity. From this perspective, creativity is a phenomenon that depends on the interactions between people and contexts (Loi \& Dillon, 2006), with the latter being family, teachers and creative models in the development of creativity (Sternberg \& Lubart, 1997).

Furthermore, it is important to remember that teachers have the responsibility of developing their students' capacities. Nevertheless, it is really easy how teachers use resources and methods that do not increase the creativity of their students.

\section{The Situation of the Musical Education in Spain}

In terms of weekly hours of the Musical Educational subject in Primary Education in the Spanish territory varies greatly, since, as summarized in the report on the weekly distribution by courses or subjects in Primary Education (UGT, 2014) while in Autonomous Communities such as Cantabria or Extremadura, have an hour, in others (such as La Rioja) there are three weekly hours available for Art Education, leaving freedom of choice to the centres to distribute them 
among Plastic Education and Music Education. To say nothing of the most striking case is the situation in Region of Murcia, where Musical Education only has one hour per week in odd courses, while in the peer courses, it disappears completely.

It is therefore complex to draw a map of Musical Education in Spain, due to the variety of teaching load is very disparate throughout the different autonomous communities, but it is clear that the teaching load is minimal. On the other hand, the Organic Law for the Improvement of Educational Quality establishes that:

"The purpose of Primary Education is to provide students with the learning of oral expression and comprehension, reading, writing, calculation, acquisition of basic notions of culture, and the habit of coexistence as well as those of study and work, artistic sense, creativity and affectivity, in order to guarantee an integral formation that contributes to the full development of the personality of the students and to prepare them to take advantage of Compulsory Secondary Education."

Having said that, there is in contradiction to what it is said by the current Educational Law because it is evident that with such a low learning load, it is really difficult to achieve an adequate musical competence, even more when there are no complementary activities (Figure 1).

\section{Music in Educative System}

Armstrong (2006) describes the musical intelligence as the capacity that every human has to differentiate, change, perceive and express different sounds, and the special features of them. In another hand, Antunes (1999) explained that possibly this type of intelligence was the less assessed in our society.

It is important to remember that as Pérez Aldeguer (2012) shown, the musical capacity of a person, was not limited to the learning of musical chords, the rhythm or the harmony. Also it is essential to work the memory, concentration, attention and relax, as well as the capacity to understand, and control the emotional state of everyone.

Different authors (Reynolds \& Ou, 2010; Benitez, Díaz Abrahan, \& Justel, 2017; Gorey, 2001), explain how people who had had a good musical education in their childhood, will have positive effects in their adult life.

Authors such as Kotilahti et al. (2010), or Platel (2002) reinforce the approach of Peretz (1994), maintaining that musical aptitude has repercussions on both hemispheres of the brain since while the right hemisphere is concerned to remembering the lyrics of the songs, while that the left hemisphere is responsible of appreciating the small details of each composition. It remains therefore demonstrating once again the great importance that an adequate musical education has at a cognitive level. Authors such as Justel and Díaz Abrahan (2012) have been able to demonstrate differences in the structure and functioning of the brains in different subjects at different ages, depending on the musical training they have undergone. 


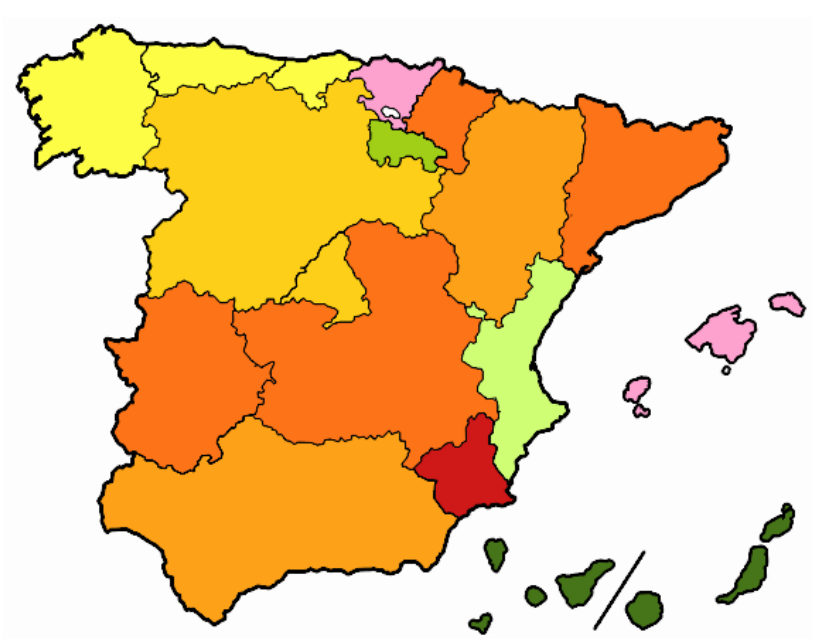

Figure 1. "Traffic Light" of the musical education in Spain. Personally created image.

\section{The Connection between Musical Education and Creativity}

In order to make an initial approach, and following to Balsera Gómez (2018), who reflects on Higueras (2010), it is potential to say that every artistic creation is the result of the combination of different cognitive functions and personal abilities. It is therefore that Balsera Gómez's work (2018), invites to reach the conclusion that a person who has an important artistic creation, will have a stronger cognitive activity than those people who copy and repeat patterns.

This is something of special relevance in the educational system, where the students' capacities must be strengthened and returning to the field of music education, although the subject is "limited" to interpret a piece of music, creative production will be presented, because never two individuals will interpret a piece in the same way.

As pointed out by Custodio and Cano-Campos (2017), when talking about the relationship between music and cognitive development, it is possible to say that "Brain changes have been clearly demonstrated after musical training, transient in non-musicians and persistent in the musicians, with correlation in the improvement of certain cognitive abilities".

Regarding to music education and following Gisbert Caudeli (2018), it is important to remember that music is presented as a vital resource in the early childhood stages for cognitive development because through sound games, songs, the musicalization of the stories, etc. It is perfectly feasible to stimulate children and doing an adequate job, it is possible to develop natural and spontaneous manifestations towards creativity. However, following Ortega and Tovar (2016), it is important to remember that early educational teachers spend very little amount of time teaching this area, arguing that they do not plan musical activities because, in addition to having a feeling of being unprepared, they lack of suitable material that guides them in the execution of this area. 


\section{Conclusion and Discussion}

Throughout this work, the relationship between music education and cognitive development has been presented, putting special emphasis on the enhancement of creativity.

As the aforementioned theorists have shown, it can be confirmed that there is a clear relationship between music education and the enhancement of creativity, since it allows the subject, "although" to be limited to the reproduction of a piece of music, will be personalizing, since as it is said in the musical slang, he interprets the piece, that is, he makes it his.

It is also important to remember that the cognitive patterns that develop both while listening to a piece of music and (and in a very special way), when interpreted, produce greater brain activity. It is therefore possible to affirm that a correct musical education throughout the academic life is necessary, since it will favour the empowerment of the different cognitive abilities of the students and especially their creativity.

In this way, and contrary to what many governments do, it is necessary, in the different stages of compulsory education, (Primary Education and Secondary Education), there is a greater teaching load in this sense and that teachers of all stages educational, have a much broader training in the didactics of music education.

However, it is also important to remember that musical education should not be understood as something isolated. It is important that this area works intrinsically to all subjects, which are really simple, and to give two examples, it is possible to work the literary metric with the lyrics of the songs and in an even clearer way since there are innumerable works in which the relationship is established, from the ratio between the length and thickness of the strings, with their sound, to elements such as harmony in its wide sense of the word.

All things considered and in the humble opinion of the authors of this work, the following changes are proposed:

- One May teacher training: the teaching load present in the Early Childhood Education degree and in the Primary Education degree, apart from the mention of Musical Education, is minimal if the purpose is to train future teachers to incorporate music in a critical and appropriate way to their academic activities, therefore it is necessary to increase the teaching load during the university career, emphasizing the creative facet of music, as it is presented by Malbrán (2009).

"It is considered a formative need to attend to the development of a Psychology of Creative Forms of Teaching" (Torrance, 1970: p. 38). It is uncommon to find in study plans for music educators subjects dedicated exclusively to the study of creativity in theoretical and applied terms.

- Rather than giving a greater teaching load to the subject of music, what it would be advisable is to work the musical education in all the subjects; nevertheless, it is necessary that teachers have an adequate musical education 
and the educational legislation allow a much more decisive role to music education.

\section{Conflicts of Interest}

The author declares no conflicts of interest regarding the publication of this paper.

\section{References}

Antunes, C. (1999). Estimular las inteligenciasmúltiples: Qué son, cómo se manifiestan, cómofuncionan. Madrid: Narcea.

Armstrong, T. (2006). Las inteligenciasmúltiplesen el aula: Guíapráctica para educadores. Barcelona: PaidósIbérica.

Balsera Gómez, F. J. (2018). Desarrollo del talentocreativo a través de la improvisaciónpianística. Creatividad y Sociedad, 27, 7-25.

http://www.creatividadysociedad.com/articulos/27/1.Desarrollo\%20del\%20talento $\% 20$ creativo $\% 20 \mathrm{a} \% 20$ traves $\% 20 \mathrm{de} \% 20 \mathrm{la} \% 20 \mathrm{improvisacion} \% 20$ pianistica.pdf

Benitez, M. A., Díaz Abrahan, V. M., \& Justel, N. R. (2017). Beneficios del entrenamiento musical en el desarrolloinfantil: unarevisiónsistemática. Revistainternacional de educación musical, no 5. https://doi.org/10.12967/RIEM-2017-5-p061-069 http://www.revistaeducacionmusical.org/index.php/rem1/article/view/100/59

Chyle, F. (1999). Applying Creativity Dance/Movement Therapy and the Creative Process. http://tanzundtherapie.de/nl/_files/nl/206/Applying\%20Creativity-Thesis.pdf

Corbalan Berná, J. (2008). ¿De qué se hablacuandohablamos de creatividad? Cuadernos de la Facultad de Humanidades y CienciasSociales. Universidad Nacional de Jujuy, 35, 11-21.

http://www.scielo.org.ar/scielo.php?script=sci_arttext\&pid=S1668-81042008000200001 \&lng=es\&tlng $=\mathrm{es}$

Costa, O. (2017). Hábitoslectores e inteligenciacreativa de losestudiantes de educaciónprimaria. Tesis doctoral, Madrid: Universidad Autónoma de Madrid.

Custodio, N., \& Cano-Campos, M. (2017). Efectos de la músicasobre las funcionescognitivas. Revista de Neuro-Psiquiatría, 80, 60-69.

Díaz, M. (2009). Una mirada a la creatividad: La visión del alumnado de Primaria. RevistaCreatividad y Sociedad, $\mathrm{n}^{\circ} 13$.

http://www.creatividadysociedad.com/articulos/13/Creatividad\%20y\%20Sociedad.\%20 Una\%20mirada\%20a\%20la\%20creatividad.\%20La\%20visi\%C3\%B3n\%20del\%20alumna do\%20de\%20primaria.pdf

Gisbert Caudeli, V. (2018). La creatividad musical comoherramientaeducativa para el cambio social. Creatividad y Sociedad, 27, 26-46.

http://www.creatividadysociedad.com/articulos/27/2.La\%20creatividad\%20musical\%20 como\%20herramienta $\% 20$ educativa $\% 20$ para $\% 20$ el\%20cambio\%20social.pdf

Gorey, K. M. (2001). Early Childhood Education: A Metaanalytic Affirmation of the Short and Long Term Benefits of Educational Opportunity. School Psychology Quarterly, 16, 9-30. https://doi.org/10.1521/scpq.16.1.9.19163

Griffiths, F. (2009). Introduction. In Supporting Children's Creativity through Music, Dance, Drama and Art (pp. 17-23). London: Routledge.

Herrera, L., Hernández-Candelas, M., Lorenzo, O., \& Ropp, C. (2014). Influencia del en- 
trenamiento musical en el desarrollocognitivo y lingüístico de niños de 3 a 4 años. $R e$ vista de Psicodidáctica, 19, 367-386. https://doi.org/10.1387/RevPsicodidact.9761

Higueras, F. (2010). Interpretación musical y creatividad: aplicacionesdidácticas. EnMúsica y Educación, 81, 34-45.

Huidobro-Salas, T. (2002). Una definición de la creatividad a través del estudio de 24 autos seleccionados. Tesis doctoral, Departamento de PsicologíaBásica, Universidad Complutense de Madrid. http://eprints.ucm.es/tesis/psi/ucm-t25705.pdf

Iniesta Masmano, R. (2014). Música/Cuento: Un Sistema Emocional. Revista Internacional de Sistemas, No. 19, 47-61. https://www.uv.es/sesgejd/RIS/19/4.Iniesta.Musica-cuento.pdf

Justel, N., \& Díaz Abrahan, V. (2012). Plasticidad cerebral: Participación del entrenamiento musical. Suma Psicológica, 19, 97-108.

Kotilahti, K. et al. (2010). Hemodynamic Responses to Speech and Music in Newborn Infants. Human Brain Mapping, 31, 595-603.

Krumm, G., Vargas, R. J., Lemos, V., \& Oros, L. (2015). Percepción de la creatividadenniños, padres y pares: Efectosen la produccióncreativa. Pensamiento Psicológico, 13, 21-32.

Loi, D., \& Dillon, P. (2006). Adaptive Educational Environments as Creative Spaces. Cambridge Journal of Education, 36, 363-381. https://doi.org/10.1080/03057640600865959

Malbrán, S. (2009). La creatividad de los maestros y la educación musical. Revista Creatividad y Sociedad, No. 13, 80-105.

http://www.creatividadysociedad.com/articulos/13/Creatividad\%20y\%20sociedad.\%20 La\%20creatividad\%20de\%20los\%20maestros\%20y\%20la\%20educacion\%20musical.pdf

Ortega, E., \& Tovar, M. (2016). Actividades musicales comoestrategiadidáctica para el Fomento de la enseñanza musical enlosniños de Educacióninicial de la U.E. "Carmen María Rodríguez” en Palma Sola, municipio Juan José Mora, estado Carabobo.

Peretz, I. (1994). Les agnosiesauditives. In X. Seron, \& M. Jeannerod (Eds.), Neuropsychologie, Humaine (205-213). Lieja: Mardaga.

Pérez Aldeguer, S. (2012). Didáctica de la expresión musical en EducaciónInfantil. Valencia: PSYLICOM.

Platel, H. (2002). Neuropsychology of Musical Perception: New Perspectives. Brain, 125, 223-224. https://doi.org/10.1093/brain/awf078

Reynolds, A., \& Ou, S. (2010). Early Childhood to Young Adulthood: Intervention and Alterable Influences on Well Wellbeing. Children and Youth Services Review, 32, 1045-1053. https://doi.org/10.1016/j.childyouth.2010.03.024

Rothenberg, \& Hausman (1976). The Creativity Question. Durham, NC: Duke.

Sternberg, R. J., \& Lubart, T. I. (1997). La creatividad en una cultura conformista. Un desafío a las masas. Barcelona: Paidos.

Torrance, E. P. (1970). Encouraging Creativity in the Classroom. Dubuque: WM.C. Brwon Company Publishers

UGT FETE Enseñanza (2014). Distribución Horaria Semanal Por Cursos y materiasen Educación Primaria. Implantación LOMCE por Comunidades Autónomas. https://es.slideshare.net/mdoloresal1/ga-bmaterias-primarialomce 